\title{
Factors Affecting Student's Academic Dishonesty During Covid-19 Pandemic
}

\author{
Gipta Sari Wahyuni*, Amy Fontanella, Sukartini \\ Accounting Department \\ State Polytechnic of Padang \\ Padang, Indonesia \\ *giptasari19@gmail.com, amyfontanella99@gmail.com, tiensukartini28@gmail.com
}

\begin{abstract}
This study aims to investigate the influence of motivation, personality traits, perceived opportunities, student attitudes, and actions taken by students on academic dishonesty in online learning during the Covid-19 pandemic. The population of this study were students majoring in Accounting, DIII and DIV Accounting, Padang State Polytechnic. The results of this study indicate the variable personality traits have a negative effect on the behavior of student academic e-dishonesty. This study also found that student attitudes and actions taken had a positive effect on academic e-dishonesty and personality traits had a negative effect on academic e-dishonesty. Meanwhile variable motivation and perceived opportunity had no effect on academic e-dishonesty.
\end{abstract}

Keywords-academic e-dishonesty, motivation, personality traits, perceived opportunity, student attitude, taking action

\section{INTRODUCTION}

The world is being hit by a global epidemic, this outbreak is named coronavirus disease 2019 (COVID-19) which is caused by Severe Acute Respiratory Syndrome Coronavirus-2 (SARSCoV-2) [1]. The first COVID-19 was reported in Indonesia on March 2nd, 2020, in two cases. March 31st, 2020 data shows that there are 1,528 confirmed cases and 136 deaths. The mortality rate for COVID-19 in Indonesia is $8.9 \%$, this figure is the highest in Southeast Asia [2]. In anticipation of the rampant Covid-19 spreading in Indonesia, the Indonesian government has taken various ways by starting the application of social distancing with staying/work from home (WFH), to the community since March 2020, where with this policy there have been many patterns of changes in community activities. Changes in activity patterns from various fields also affect activities in the field of education.

The President of Indonesia and based on the Circular of the Ministry of Education and Culture No.4 of 2020, contains a temporary delay in face-to-face learning which is commonly carried out by educators and students with learning through internet / online media (e-learning) ), both at the school level and at the college level. Law No. 20 of 2003 regarding the national education system states that education is a conscious and planned effort to create an atmosphere of learning and the learning process so that students actively develop their potential to have religious spiritual strength, self-control, personality, intelligence, noble character as well as skills needed by himself, society, nation and state. Conscious and planned efforts to create a learning atmosphere for selfpotential development are threatened by the discovery of fraudulent practices [3]. Learning through the internet / online (e-learning) is said to be an effort to optimize the occurrence of "learning events" by applying information and communication technology appropriately [4].

The implementation of online learning is expected to be able to educate students to be able to carry out learning properly in accordance with lecture rules, because many consider students to be intellectuals or educated who are considered capable of solving problems with honesty. Especially in the current situation, students who are needed are students who are responsive to problems, tough and reliable and of course always uphold the values of truth. In online learning currently implemented, there are many problems in the learning process, especially with the level of honesty that is inversely proportional to the expectations of the nation. Students in general are value oriented, because value is considered as a measure of a person's success so that all means are done to be able to achieve the target value, including by committing academic dishonesty [5]. Related to this aspect of academic honesty, online learning is very likely that students as learners commit academic dishonesty, especially with online learning it will be more difficult to detect dishonesty when compared to face-to-face learning. The opportunities offered by the Internet for interpersonal communication, storage, and dissemination of information have brought many benefits to the university environment. The new technologies have changed the achievement of the teaching-learning process, the design and development of research projects, and the writing of scientific articles. However, with these positive changes, there has also emerged the reverse: cheating, fraud, piracy [6].

The problem of academic dishonesty has been widely discussed by researchers who have an interest in academic dishonesty committed by students. Academic integrity is honesty in all matters related to the academic environment [7]. The multiple environments include the teaching-learning 
process, abilities, values and the discovery of new knowledge. Most common in the application of academic integrity is the prohibition of cheating behavior, acts of plagiarism in writing assignments, or falsifying documents for institutions. Academic integrity is the basic value of all educational activities. Academic dishonesty is a violation of academic integrity.

Motivation has no influence on the academic fraud behavior of accounting students as prospective study accountants for accounting students at the Islamic University of Indragiri [8]. The motivation to cheat may be higher, again leader to cognitive dissonance [9]. The results of this study are also in line with the research conducted by Wardana [10], this study also shows a negative and significant influence of learning motivation on academic fraud in students majoring in accounting at the Ganesha University of Education undergraduate program. Based on these findings, the first hypothesis is formulated;

$\mathrm{H}_{1}$ : Motivation has a negative effect on academic dishonesty in online learning.

Personality traits are also an influencing factor in academic dishonesty, in her research it is stated that personality traits have a significant negative result on academic dishonesty [11]. The study that have done in pakistan about personality traits are also has a negative impact to academic dishonesty among students [12]. Therefore, the second hypothesis is formulated;

$\mathrm{H}_{2}$ : Personality traits have a negative effect on academic dishonesty in online learning.

Opportunity is a condition that allows for cheating. Research conducted by Wardana [10], shows a negative and significant opportunity effect on academic fraud in accounting students majoring in Ganesha University's undergraduate program. This is also in line with research Yulianti which also shows that perceived opportunities have a significant negative effect on academic dishonesty habits [13]. On the basis of these findings, the third hypothesis is formulated;

$\mathrm{H}_{3}$. The perceived opportunity has a negative and significant effect on academic dishonesty in online learning.

Student attitudes are related to the attitudes of students towards their lecturer responses and the factors they consider when faced with evidence of academic dishonesty [14]. With an attitude of academic success being the number one priority [9]. Post-intervention attitude scores were significantly improved compared to baseline scores for the control and intervention groups, indicating a positive relationship with exposure to the information, with a greater improvement among intervention group participants [15]. One of the most factors that impact academic dishonesty is an attitude for doing an academic dishonesty. Therefore, the fourth hypothesis can be formulated, namely:

$\mathrm{H}_{4}$ Student attitudes have a negative and significant effect on academic dishonesty in online learning.
Tthe actions taken by students are also related to beliefs about the actions that the department should take in handling online academic dishonesty [14]. So, the fifth hypothesis can be formulated, namely:

$\mathrm{H}_{5}$ : Actions taken have a negative and significant effect on academic dishonesty in online learning.

\section{RESEARCH METHODS}

This research was conducted at Padang State Polytechnic Accounting Department DIII and DIV Study Program. This study aims to determine the variables that influence academic cheating behavior during online learning for students. The population in this study were students majoring in Accounting, the DIII Study Program with an active status for the 2017-2019 school year and the Accounting DIV Study Program with an active status for the 2016-2019 academic year at Padang State Polytechnic.

The sampling technique was purposive sampling. In this study, the data used are quantitative data. Quantitative data is data that can be measured with a scale numeric or in the form of numbers. The primary data from this study is a questionnaire with related respondents who conducted online learning during the Covid-19 pandemic. The method of quantitative analysis is carried out using statistical analysis (SPSS), which is a simple method of analysis. The statistical tests carried out in this study were (1) data quality test consisting of validity and reliability tests (2) classical assumption tests consisting of normality test, multicollinearity test, and heteroscedasticity test, (3) determination coefficient hypothesis test.

\section{RESULTS AND DISCUSSION}

The characteristics of the 150 questionnaires that can be processed are as follows Table 1:

TABLE I. RESPONDENT CHARACTERISTICS

\begin{tabular}{|c|c|c|}
\hline Criteria & Frequency (Person) & Percentage (\%) \\
\hline \multicolumn{3}{|l|}{ Studies Program } \\
\hline DIII & 54 & $36 \%$ \\
\hline DIV & 96 & $64 \%$ \\
\hline \multicolumn{3}{|l|}{ Year } \\
\hline 2016 & 55 & $36.7 \%$ \\
\hline 2017 & 35 & $23.3 \%$ \\
\hline 2018 & 36 & $24 \%$ \\
\hline 2019 & 24 & $16 \%$ \\
\hline \multicolumn{3}{|l|}{ Gender } \\
\hline Male & 44 & $29.3 \%$ \\
\hline Female & 106 & $70.7 \%$ \\
\hline
\end{tabular}

Based on the Table 1 above, shows that respondents in this study is dominated by students of as much as 96 DIV Accounting people or $64 \%$, while the students of the DIII Accounting Study Program were only 54 people or $36 \%$, then for the batch of 2016 the most number was the 2016 class with 55 respondents or $36.7 \%$, and the last was from gender, women were more dominant, namely as many as 106 people or $70.7 \%$ while only 44 men or $29.3 \%$ men. 
TABLE II. DESCRIPTIVE STATISTICS

\begin{tabular}{|l|l|l|l|l|c|}
\hline & \multicolumn{1}{|c|}{$\mathbf{N}$} & \multicolumn{1}{|c|}{ Min } & \multicolumn{1}{|c|}{ Max } & Mean & Std. Deviasi \\
\hline $\mathrm{X} 1$ & 150 & 12 & 33 & 23.91 & 3.454 \\
\hline $\mathrm{X} 2$ & 150 & 12 & 37 & 29.48 & 4.411 \\
\hline $\mathrm{X} 3$ & 150 & 4 & 8 & 6.52 & 918 \\
\hline $\mathrm{X} 4$ & 150 & 4 & 8 & 6.13 & 929 \\
\hline $\mathrm{X} 5$ & 150 & 8 & 16 & 12.51 & 1.518 \\
\hline Y & 150 & 13 & 48 & 21.89 & 5.386 \\
\hline $\begin{array}{l}\text { Valid N } \\
\text { (Listwise) }\end{array}$ & 150 & & & & \\
\hline
\end{tabular}

Based on the table 2 above, it can be seen that the minimum, maximum, mean, and standard deviation values of the variables indicate that the average respondent chooses a score of 1 to 4.

After the descriptive statistical test is carried out, then the data quality test is carried out consisting of the validity test and reliability test. The validity test of the measuring instrument in this study was carried out by comparing the value of the Correlated Item-Total Correlation on each item of the statement with the value of the product moment rtable. If the value of Correlated Item-Total Correlation (rcount)> rtabel value and the value is positive, then the statement items on each research variable are declared valid [16]. Based on the validity test, each question item shows the Correlated ItemTotal Correlation (rcount)> rtabel value and the value is positive. This means that the question items used in this study are valid. In this study all questions on the variable are declared valid, because the calculated $r$ value is greater than the $r$ table value and is positive. So it can be concluded that all questions can be used to measure student academic dishonesty variables during online learning.

TABLE III. RELIABILITY TEST RESULTS

\begin{tabular}{|l|l|l|l|}
\hline \multicolumn{1}{|c|}{ Variable } & \multicolumn{1}{c|}{$\begin{array}{c}\text { Cronbach's } \\
\text { Alpha }\end{array}$} & r Table 5\%(30) & Information \\
\hline E-Dishonesty & 0,772 & 0,159 & Reliable \\
\hline Motivation & 0,752 & 0,159 & Reliable \\
\hline $\begin{array}{l}\text { Personality } \\
\text { Traits }\end{array}$ & 0,829 & 0,159 & Reliable \\
\hline $\begin{array}{l}\text { Perceived } \\
\text { Opportunity }\end{array}$ & 0,405 & 0,159 & Reliable \\
\hline Student Attitude & 0,231 & 0,159 & Reliable \\
\hline Taking Action & 0,639 & 0,159 & Reliable \\
\hline
\end{tabular}

Based on the table 3, the value of Cronbach's alpha is greater than the $\mathrm{r}$ table, so the data is reliable, this means that the variable motivation $\left(\mathrm{X}_{1}\right)$, personality traits $\left(\mathrm{X}_{2}\right)$, opportunity $\left(\mathrm{X}_{3}\right)$, student attitude $\left(\mathrm{X}_{4}\right)$, taking action $\left(\mathrm{X}_{5}\right)$ and academic e-dishonesty (Y) in this study is reliable.

TABLE IV. Multiple LineAR REgRESSION TEST RESUlts

\begin{tabular}{|c|c|c|c|c|c|c|}
\hline \multirow{2}{*}{\multicolumn{2}{|c|}{ Model }} & \multicolumn{2}{|c|}{ Unstandardized Coefficients } & \multirow{2}{*}{\begin{tabular}{|c|} 
Standardized Coefficients \\
Beta \\
\end{tabular}} & \multirow[b]{2}{*}{$\mathbf{T}$} & \multirow[b]{2}{*}{ Sig. } \\
\hline & & $B$ & Std. Error & & & \\
\hline 1 & (Constant) & 31.118 & 5.010 & & 6.211 & 0.000 \\
\hline & Motivation & 0.024 & 0.135 & 0.016 & 0.180 & 0.857 \\
\hline & Personality Traits & -0.735 & 0.101 & -0.602 & -7.271 & 0.000 \\
\hline & Perceived Opportunity & -0.214 & 0.414 & -0.036 & -0.517 & 0.606 \\
\hline & Student Attitude & 1.155 & 0.386 & 0.199 & 2.996 & 0.003 \\
\hline & Taking Action & 0.494 & 0.246 & 0.139 & 2.008 & 0.047 \\
\hline
\end{tabular}

Dependent Variable: Academic E-Dishonesty

Source: Data processed in 2020

Based on the table 4, the regression equation is obtained as follows: $\mathrm{Y}=31,118+0.024-0.735-0.214+1.155+0.494$. From this equation it can be interpreted that a constant of 31,118 means that if motivation (X1), personality traits (X2), perceived opportunity (X3) student attitude (X4) and taking action (X5) are considered constant, then on average behavior academic e-dishonesty (Y) of 31,118 levels. If the variable has increased by 1 level, then academic e-dishonesty (Y) can decrease or increase according to data B on Unstandardized Coefficients.

The above shows that the variable personality traits has a negative influence on behavioral acts of academic edishonesty. If the low value personality traits, then academic edishonesty will increase due to the low personality traits, it will make academic e-dishonesty more and more being carried out among students. The results of this study are in line with the research conducted by sari [11], meaning that the hypothesis $\left(\mathrm{H}_{2}\right)$ above is accepted .

Then for the student attitude variable and taking action carried out by students shows a positive influence, meaning that the students are more indifferent or silent when they find out about the incident of academic e-dishonesty, and students do not know well the sanctions received when conducting academic e-dishonesty, then will increase or increase the number of incidents of this academic e-dishonesty. In the research conducted by researchers, this is not in line with research conducted by Peled [14] which states that student attitude and taking action have a negative effect on academic edishonesty. Then the hypotheses $\left(\mathrm{H}_{4}\right.$ and $\left.\mathrm{H}_{5}\right)$ above are rejected.

Meanwhile, variable motivation and perceived opportunity have no influence on the occurrence of academic e-dishonesty, in the sense that motivation to learn is a non-intellectual 
psychological factor. Its unique role is in the development of passion, pleasure and enthusiasm for learning. The results of this study indicate that learning motivation has no effect on academic cheating behavior, this is contrary to research conducted by Wardana [10] which shows that motivation has a negative effect on academic dishonesty, so that $\mathrm{H}_{1}$ above is not accepted. As for the variable perceived opportunity, it shows that dealing with academic dishonesty will make students waste time on this and not focus on other things. This shows that the results of this study are not in line with research conducted Yulianti [13] and Wardana [10], which shows that this variable perceived opportunity has a negative effect on academic e-dishonesty. Therefore, $\mathrm{H}_{3}$ above is rejected.

TABLE V. T-TEST RESULTS

\begin{tabular}{|c|c|c|c|c|}
\hline Model & R & $\begin{array}{c}\text { R } \\
\text { Square }\end{array}$ & $\begin{array}{c}\text { Adjusted R } \\
\text { Square }\end{array}$ & $\begin{array}{c}\text { Std. Error of } \\
\text { the Estimate }\end{array}$ \\
\hline 1 & $0,655^{\mathrm{a}}$ & 0,429 & 0,410 & 4.139 \\
\hline
\end{tabular}

Based on table 5 above, it can be seen that the value is Adjusted R Square 0.410. This means that the behavior of academic e-dishonesty (Y) can be explained by motivation (X1), personality traits (X2), perceived opportunity (X3) student attitude (X4) and taking action (X5) by $41 \%$. While the remaining $59 \%$ is explained by other variables outside this research model.

\section{CONCLUSION}

The purpose of this research is to determine the influence of motivation variables, personality traits, perceived opportunities, student attitudes and actions or actions on online academic dishonesty during online learning. Based on the research hypothesis testing, the factors that influence student academic dishonesty during online learning during the Covid19 pandemic are personality traits, perceived opportunity, student attitude and action taking.

\section{SUGGESTION}

This study has limitations, the object under study is only students majoring in accounting, so the results of the research cannot be generalized to the Padang State Polytechnic as a whole. Therefore, it is suggested to further researchers to expand the research object of majors other than accounting so that the research results can be generalized. Furthermore, regarding the motivation variable, the researcher only explains motivation in general, so that the respondent does not understand the meaning of motivation. Therefore, it is suggested to the next researchers to be able to broaden the picture of motivation, so that respondents can better understand the motivation related to the research. In online learning in this covid-19 condition, it is hoped that the abuse of internet resources can be minimized with early notification from the lecturer, either in writing or not.

\section{REFERENCES}

[1] A. Susilo et al., "Coronavirus Disease 2019: Tinjauan Literatur Terkini," J. Penyakit Dalam Indones., vol. 7, no. 1, p. 45, 2020.

[2] WHO (World Health Organization), "Updated WHO recommendations for international traffic in relation to COVID-19 outbreak." https://www.who.int/news-room/articles-detail/updated-whorecommendations-for-international-traffic-in-relation-to-covid-19outbreak.

[3] R.I. Undang-Undang, "no. 20 tahun 2003 tentang Sistem Pendidikan Nasional," Bandung: Citra Umbara, 2003.

[4] U.A. Chaeruman, "Alur Belajar: Meningkatkan Interaktivitas Pembelajaran Daring," Semin. Lokakarya Pembelajaran Daring di Perguru. Tinggi, no. September, pp. 1-10, 2017.

[5] N. Amalia, "Hubungan goal orientation dan motivasi berprestasi dengan intensi menyontek pada mahasiswa program studi psikologi universitas mulawarman," eJournal Psikol., vol. 4, no. 3, pp. 295-306, 2016.

[6] L. Mâță, I.M. Lazăr, and R. Ghiațău, "Exploring Academic Dishonesty Practices Among Science Education University Students ISSN 16483898 ISSN 2538-7138," pp. 91-107.

[7] A. Ardinansyah, D. Tenrisau, F. Aslim, and I.S. Wekke, "Ketidakjujuran Akademik Dalam Pendidikan Tinggi," no. 20, 2018.

[8] R. Melasari, "Pengaruh Motivasi Belajar, Penyalahgunaan Teknologi Informasi Dan Integrasi Mahasiswa Terhadap Perilaku Kecurangan Akademik Mahasiswa Akuntansi Sebagai Calon Akuntan (Studi Pada Mahasiswa Akuntansi Universitas Islam Indragiri)," Akunt. dan Keuang., vol. 8, no. 1, pp. 79-93, 2019.

[9] B. Hendricks, "Academic Dishonesty: A Study in the Magnitude of and Justifications for Academic Dishonesty Among College Undergraduate and Graduate Students," J. Coll. Student Dev., vol. 5, no. 3, pp. 212 260, 2004.

[10] G.J. Wardana, "Pengaruh Motivasi Belajar, Integritas Mahasiswa Dan Penyalahgunaan Teknologi Informasi Terhadap Perilaku Kecurangan Akademik (Studi Kasus Pada Mahasiswa Jurusan Akuntansi Program S1 Universitas Pendidikan Ganesha)," JIMAT (Jurnal Ilm. Mhs. Akunt. S1), vol. 8, no. 2, 2017.

[11] S.Y.S.W.A. Sari, "Peran the Big Five Personality Traits Terhadap Academic Dishonesty Pada Mahasiswa," vol. 9, no. 3, pp. 267-275, 2017.

[12] M.S. Aslam and S.N. Mian, "The Impact Of Personality Traits On Academic Dishonesty Among Pakistan Students," J. Commer., vol. 3, no. 2, p. 50, 2011.

[13] P. Yulianti, I.B.A. Permana, and P.P. Paramita, "Self control, perceived opportunity, knowledge and attitude as predictors of plagiarism by undergraduate students," Int. J. Innov. Creat. Chang., vol. 11, no. 11, pp. 556-571, 2020.

[14] Y. Peled, Y. Eshet, C. Barczyk, and K. Grinautski, "Predictors of Academic Dishonesty among undergraduate students in online and faceto-face courses," Comput. Educ., vol. 131, no. October 2017, pp. 49-59, 2019.

[15] I.R. Azulay Chertok, E.R. Barnes, and D. Gilleland, "Academic integrity in the online learning environment for health sciences students," Nurse Educ. Today, vol. 34, no. 10, pp. 1324-1329, 2014

[16] I. Ghozali, “Aplikasi Analisis Multivariate dengan program SPSS edis 3," Semarang Badan Penerbit Univ. Diponegoro, 2005. 